\title{
Conflict of Kadie Mandati Tradition Institution
}

\author{
Paisal Halim, Abdul Rahim, Syamsiah Badruddin \\ Universitas Indonesia Timur, South Sulawesi, Indonesia \\ Paisalhalim[at]gmail.com, rboda89[at]yahoo.co.id, chiah_jurnal2006[at]yahoo.com
}

\begin{abstract}
This study aims to find the driving factor of traditional conflict institutions of Kadie Mandati and the solutions of traditional institutions conflict. This research used a qualitative approach by using the in-depth interview as collecting data. The informant of this study was assigned as much 12 informants drawn at random way. Documentation and interviews are used to collect the data and analyzed by content, grammatical and historical interpretation analysis. The research concludes that The three factors driving the occurrence of dualism conflict of the indigenous institution in Kadie Mandati are legal, political and cultural factors. The conflict can be resolved through three solutions consist of: Firstly, the declaration of Sultan Buton regarding the determination of legitimate traditional institutions in Kadie Mandati (Peacekeeping). Secondly, the revitalization LAKM as Kadie Mandati Indigenous Institute (peacemaking). Moreover, thirdly is political will in Wakatobi in the form of local regulations aimed at ensuring legal certainty and protecting the interests of indigenous peoples (Peacebuilding).
\end{abstract}

Keywords: Law, Cultural, Traditional Institutions

\section{Introduction}

Law and community life have a very close relationship in achieving safe and peaceful life. The law serves to maintain public order and harmonious life style. The role of law as controlling change in the dynamics of society, law develops in conjunction with developments in society. Law plays a role in social control in two forms: preventive and repressive. Social dynamics in society continues to occur and can disrupt stability and order. Law plays a defensive role in preventing the emergence of disturbance of the balance between flexibility with the dynamics of society. The common repressive law aims to achieve balance after the occurrence of social disorders. (Teubner, 1983) (Meško \& Lobnikar, 2005). The important role of law in society is significant in the social order. As a social contract and collective agreement result, legal protection must be done to eliminate social conflict. Every member of society should be involved in maintaining the existence of the law. The social purpose of the law can be realized, if all members of society are subservient and observe the rules of law which are both written (the rule of law) and unwritten (the existing law). However, in the dynamics of people's lives, differences and conflicts of interest among members of society are often unavoidable.

Customary law is one of the systems of legal system governing social life of social and social life in Indonesia. The customary law comes from unwritten rules that develop and become a guide to the legal consciousness of its people. Customary law is elastic and evolves according to the progress of society. However, customary law has a weakness of conflict. (Hadfield, 2017)

The institution is a set of relationship norms, beliefs and the real value that grows with the social needs of a community (Bott \& Spillius, 2014). In Indonesian civil society organizations formed shaped as traditional institutions (Uyeda et al., 2016). Traditional institutions are used to help local government and become partners in empowering local governments, to preserve and develop their culture.
The social institution conflicts occurred in Wangi-Wangi Selatan Sub-district, Wakatobi Regency, Southeast Sulawesi Province. The conflicts of customary institutions were triggered by the birth of a new customary institution in 2007 under the name of Lembaga Adat Mandati Besar (LEAMA). Previously, there was traditional institution Lembaga Adat Kadie Mandati (LAKM) which has long received social recognition as a legitimate customary institution in Kadie Mandati.

The social contract perspective, LAKM is trusted by the Buton Sultanate and the indigenous community of Kadie Mandati to manage the assets of indigenous peoples in the form of land, forests, and waters for the benefit of the community. In Buton's historical record, "Kadie Mandati" is one of 72 kadie in the territory of the Buton Kingdom. Kadie is a Buton language which is equivalent to the 'autonomous region' parallel to its status with the duchy/ district. Kadie is led by a 'Lakina or King' who is titled 'Lakina Mandati.' After Indonesia gained independence in 1945, Kadie Mandati changed its name to Mandati Village which at that time was first led by a Chairman. The transformation of leader institution based on the conform with the system of government. In 1949, the title of "Chairman" was replaced by the title of "Kepala Desa." While the Kadie Mandati institutionally was still running as usual. This institution has autonomous self-government according to the mandate of the Sultanate of Buton, which is a customary institution, has a board, has an identity, owns assets (wealth) which are managed based on the government system of the sultanate of Buton.

Lembaga Adat Mandati Besar (LEAMA), which then claimed all the assets of indigenous peoples that have been managed and maintained for generations by LAKM. Several usual and customary forest areas were taken over by management even among them sold by LEAMA officials in the name of indigenous peoples (on behalf of indigenous peoples). Until now, the two customary institutions have claimed the authority and assets of indigenous peoples both in the form of forest, land, and water and nonphysical in the 


\section{International Journal of Science and Research (IJSR) \\ ISSN (Online): 2319-7064}

Index Copernicus Value (2015): 78.96 | Impact Factor (2015): 6.391

shape of authority, rights, and obligations without any common ground.

The Constitution of the Supreme Court of the Republic Indonesia Number 2603K/Pdt/2014 at April 30, 2015 (Supreme Court Decision 2603K) stating that the 39th Sultan Buton is still legally customary and the law serves as Sultan Buton and his customary institutions under his rule include LAKM. Social conflicts arise due to the uncertain political will of the local government and seem to support the presence of LEAMA. The reason of local authorities is based on national. Until now, each traditional institutions are claiming authority and assets of indigenous peoples both in physical forms such as forests, soils, and waters. The institutions also claim the non-physical form of authority, rights, and obligations in the absence of common ground.

Social conflicts in society arise because of the expectation of the values higher and protective measures in a situation of insecurity or external instability. Conflict shaped recovery efforts of reconstruction and reconciliation state legitimacy (Shah \& Cardozo, 2014). Emphasizes the importance of impartiality mediation actions involving both parties to achieve neutrality, and expanded communication between the parties. A key aspect of mediation is a commitment to resolve the conflict based on mutual understanding and peaceful purposes (Dhiaulhaq, De Bruyn, \& Gritten, 2015). Based on the fact about the conflict, this article describes the driving factor of traditional conflict institutions of Kadie Mandati.

\section{Research Method}

This study is the normative and sociology legal research and located at Kadie Mandati, Wangi-Wangi, Wakatobi in Southeast of Sulawesi, Indonesia. Population includes all indigenous peoples in Kadie Mandati totaling 13041 people who spread across in three districts. The informant of this study was assigned as much 12 informants drawn at random way. Documentation and interviews are used to collect the data and analyzed by content, grammatical and historical interpretation analysis.

\section{Result and Discussion}

\subsection{The driving factor of traditional conflict institutions}

Various opinion from informants about the causal factors of customary agency conflict. The first opinion explains that the cause of the conflict was the absence of the informed Sultan Buton in writing of the establishment of a legitimate customary institution at Kadie Mandati. Sultan Buton who has customary legitimacy should decide on the manager of Kadie Mandati's customary assets. Although LAKM has been traditionally and recognized by hereditary Sultan Buton as a legal institution in Kadie Mandati. In fact, the Sultanate of Buton has communicated with the local government regarding the decision of the Constitutional Court about the existence of Kadie Mandati customary institution as a legitimate institution in Wangi Wangi Subdistrict, Wakatobi Regency. The Constitutional Court's verdict confirms that all customary institutions residing in the sultanate region of Buton remain in force.

The second opinion from the informant is the absence of regulations made by the local government regarding the legitimate customary law institution as stipulated in the decision of the Supreme Court.

The importance of legitimacy from Local Government is very necessary for the settlement of the conflict between the two bodies. One of the authorities of the local administration based on Constitution Number 23 The year 2014 about Local Government states that to establish a Regional Regulation governing the official customary institution is one of the legal efforts that legitimize social organization. Customary institutions have full authority and are structured as government partners. Customary institutions become supporters of the social governance unit of the community.

The third opinion is the low retirement of local government to solve the conflict of the dualism of custom institution in Kadie Mandati. In fact, the Kadie Mandati customary institution called "Sara" by the community has a notarial document as the government requirement. These institutions play a role in protecting cultural and customary assets and acting in the affairs of ulayah land, protecting customary forest assets and becoming mediators when disputes occur among citizens. Nevertheless, the Mandati Besar Adat Institute also claims that its agencies have authority over the management of customary assets, including customary forests. Both local institutions are trying to attract government sympathy to get the legality of authority.

The fourth opinion is the attitude of the two customary institutions. Neither side has ever met to find a solution to the conflict. Moreover, no person or unit serves as a mediator in conflict resolution. Collective agreements can be established through the equality of attitudes and perceptions about the protection of Mandati's customary assets.

The fifth opinion is the ambition of both customary institutions to control the property of indigenous peoples. Indigenous land which is a major supporter of regional development facilities is targeted by investors. The surface area of customary land (Tanah adat) is decreasing with the growth of tourism infrastructure, especially in Wangi Wangi Selatan Subdistrict. Conflict occurs because of domestic institutions. Mandati Besar often negotiates the transfer of rights and the sale of customary land while Kadie Mandati Traditional Institution (old institution) seeks to maintain the symbol of land as an element to maintain family ties. Land is not only worth the land or space but has a symbol of selfesteem.

The fifth opinion is a matter of identity. The value of customary institutions as the identity of a community is characterized by efforts to conserve and protect the land, forests and marine resources. However, with the urgency of regional development, the identity is increasingly faded.

Based on the above five opinion explanations, the conflict driving factors of customary institutions can be grouped into

\section{Volume 6 Issue 8, August 2017}




\section{International Journal of Science and Research (IJSR) \\ ISSN (Online): 2319-7064}

Index Copernicus Value (2015): 78.96 Impact Factor (2015): 6.391

three main factors namely legal factors, political factors, and cultural factors.

Table 1: Classification of driving factors

\begin{tabular}{|c|l|l|l|}
\hline Driving factors & Law & Political & Culture \\
\hline Intimation of Sultan Buton & & & \\
\hline Local regulation & & & \\
\hline $\begin{array}{c}\text { The attitudes of the local } \\
\text { government }\end{array}$ & & & \\
\hline $\begin{array}{c}\text { The attitudes of conflicted } \\
\text { Indigenous Institute }\end{array}$ & & & \\
\hline $\begin{array}{c}\text { Assets of Indigenous } \\
\text { community }\end{array}$ & & & \\
\hline Public attitudes & & & \\
\hline Identity & & & \\
\hline
\end{tabular}

\subsection{Law Factors}

Legal recognize in writing toward an institution is an embodiment of legal certainty. Hence, an institution can maintain its existence and authority. Sultan Buton has not issued a written notice regarding the traditional legal institutions in KadieMandati, though customarily LAKM has been recognized for generations by Sultan Buton as traditional institutions authorized in Kadie Mandati. Also, the local regulations on traditional institutions in Wakatobi have not been formed. Promulgation of Sultan Buton and local regulations is the realization of the enforcement of the rights of indigenous peoples. The absence of written evidence regarding the validity of the status customary institutions and the lack of local regulations on traditional institutions implicated in the lack of legal standing and legal recognition.

- The non-legal status and non-legal Institutions will create vigilantism and arbitrariness actions.

- Secondly, the legal structure that is the local government and the Sultanate of Buton not responsible for overcoming the dualism traditional institutions conflict through dialogue, negotiation, mediation, and peace building after the implemented of Supreme Court Decision. The unresponsive devices such laws lead to conflicts that threaten the social purpose.

- Third, the legal culture which is the mindset of local governments and people who do not understand that the establishment of new indigenous institutions must have a normative power which is carried out according to customary law. Recruitment system of custom agency officials is tightened and closed due blood or descent must relate them with their parents or family that has served the indigenous.

\subsection{Political Factor}

There is two mode of human existence. The first mode is a tendency to "have" and the second is a tendency to "want to be" (to be) (Fromm, 2008). LEAMA organizers are the political elite who have the close relations with local government authorities. Wakatobi as a new district is needed a land for the physical development. These conditions encourage some political elites to establish LEAMA who then claimed all of the community assets that managed by
LAKM.The aim is to negotiate with the local authorities regarding the necessity of land for physical construction. LEAMA utilizes it, then easily to conduct and make decisions related to land acquisition problems. Social and psychological tensions between the two traditional institutions are frequently be seen. The mediation steps persuasively have performed by two sides to maintain the quo status that is the identity as an indigenous institution. The impact of these two factors causes the dualism conflict of traditional institutions that mentioned above, including direct and indirect effects. (Knox, Marston, \& Imort, 2016)

The direct effects that are the assets owned by indigenous peoples' in Kadie Mandati such as forests, land, and water. They are maintained and preserved by LEAMA, and indigenous peoples of Kadie Mandati intervened and exploited by LAKM. Assumed on behalf of indigenous peoples, land, and forests transferred by LEAMA to the local government for the necessity of land for the construction of office. While the indirect impact that is psychologically spawned a split in society into two group consists of groups that still accept and submit to the LAKM and others as a group that is supporting the community of LEAMA. If this condition is allowed to stand and continue without problemsolving, then it potentially to give a social conflict.

\subsection{Culture Factors}

The culture of community develops through intergenerational information. Attitudes and paradigms that affect the human mindset are based on the value of the values held. With culture, the established social relationships support the community's relationships and relationships with its natural environment. Local culture is the identity of a nation, so it becomes an important factor in a community. (Castells, 2011) (Li, 2000).

Indigenous peoples Mandati has local wisdom in the management of natural resources such as water, forests, and land. Kaindea or one of the forest management systems is understood as a rule that the forests are deliberately planted by indigenous peoples as Where the fulfillment of people's food needs in the event of a condition of famine, Strengthening social relations and functioning in a protected environment. Forest management based on local culture is divided into two namely Kaindea u'sara (customary forest) and Kaindea u'santuha (family-owned forests). The value of forest resources is not only seen as a land asset but culturally the forest is considered a social asset. Indigenous forests are not owned by a family group but are a source of community life. While family-owned forests are not only meaningful to one's own. The source of livelihood for a group of people with kinship ties.

\subsection{Conflict Resolution}

Conflict resolution is a comprehensive term which implies that the source of conflict lies in the roots and must be considered and resolved (Miall, 2003). If the conflict resolution quo is not conducted soon, it will create social conflict as opposed to social purpose. There are three stages in conflict solution consists of 1) Peacekeeping is processed

\section{Volume 6 Issue 8, August 2017




\section{International Journal of Science and Research (IJSR) \\ ISSN (Online): 2319-7064}

Index Copernicus Value (2015): 78.96 | Impact Factor (2015): 6.391

to stop or reduce conflict through the powerful intervention that performed a role as the neutral peacekeeping. 2) Peacemaking is processed whose its purpose to reconcile political attitudes and strategies of the conflicting parties through mediation, negotiation, arbitration, particularly at an elite level or leadership); and 3) Peacebuilding is processed to implement changes or reconstruction of the social, political, and economic order to create a lasting peace. Three of these stages, it can be applied to the settlement of the dualism conflict in tradition indigenous KadieMandati with the formulation.

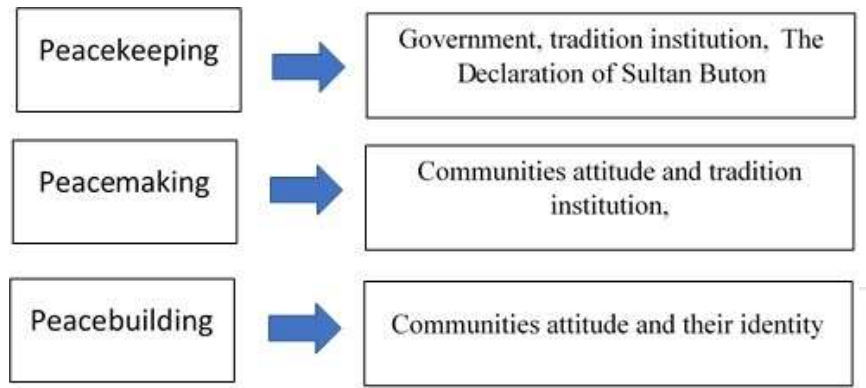

Figure 1: Three stages of settlement of the dualism conflict

The responsive action to public property on Supreme Court is publishing a notice of the determination of Sultan Buton LAKM as a legal institution in KadieMandati that can provide normative power consist of legal standing and legal Recognize. Second, the revitalization of LAKM as an assigned institution by Sultan Buton through the media of local regulations on traditional institutions. By the local regulations on the traditional institutions than the local government is obliged to implement and protect the rights of indigenous institutions guaranteed by the Constitution and international conventions. The government supervised the implementation of the obligations of customary institutions. Local regulation is a embodies the law as a tool of social communication. Third, the enforcement of local regulations on traditional institutions must be accompanied by the political will of local governments and communities that consistent with the rules.

\section{Conclusion}

The three factors driving the occurrence of dualism conflict of Indigenous Institution in Kadie Mandati are legal, political and cultural factors. The conflict can be resolved through three solutions consist of: Firstly, the declaration of Sultan Buton regarding the determination of legitimate traditional institutions in Kadie Mandati (Peacekeeping). Secondly, the revitalization LAKM as Kadie Mandati Indigenous Institute (peacemaking). Moreover, thirdly is political will in Wakatobi in the form of local regulations aimed at ensuring legal certainty and protecting the interests of indigenous peoples (Peacebuilding).

\section{References}

[1] Bott, E., \& Spillius, E. B. (2014). Family and social network: Roles, norms and external relationships in ordinary urban families. Routledge.

[2] Castells, M. (2011). The power of identity: The information age: Economy, society, and culture (Vol. 2). John Wiley \& Sons.

[3] Dhiaulhaq, A., De Bruyn, T., \& Gritten, D. (2015). The use and effectiveness of mediation in forest and land conflict transformation in Southeast Asia: Case studies from Cambodia, Indonesia and Thailand. Environmental Science \& Policy, 45, 132-145.

[4] Fromm, E. (2008). 1941Escape from Freedom. New York: Farrar and Rhinehart.

[5] Hadfield, G. K. (2017). The Problem of Social Order: What Should We Count as Law? Law \& Social Inquiry, 42 (1), 16-27.

[6] Knox, P. L., Marston, S. A., \& Imort, M. (2016). Human geography: Places and regions in global context. Pearson.

[7] Li, T. M. (2000). Articulating indigenous identity in Indonesia: Resource politics and the tribal slot. Comparative Studies in Society and History, 42 (1), 149-179.

[8] Meško, G., \& Lobnikar, B. (2005). The contribution of local safety councils to local responsibility in crime prevention and provision of safety. Policing: An International Journal of Police Strategies \& Management, 28 (2), 353-373.

[9] Miall, H. (2003). Global governance and conflict prevention. In Global Governance, Conflict and Resistance (pp. 59-77). Springer.

[10] Shah, R., \& Cardozo, M. L. (2014). Education and social change in post-conflict and post-disaster Aceh, Indonesia. International Journal of Educational Development, 38, 2-12.

[11] Teubner, G. (1983). Substantive and reflexive elements in modern law. Law and Society Review, 239-285.

[12] Uyeda, L. T., Iskandar, E., Purbatrapsila, A., Pamungkas, J., Wirsing, A., \& Kyes, R. C. (2016). The role of traditional beliefs in conservation of herpetofauna in Banten, Indonesia. Oryx, 50 (2), 296-301. 